\title{
A new species and three hybrids in the ferns from Cocos Island, Puntarenas, Costa Rica
}

\author{
Alexander Francisco Rojas-Alvarado \\ Universidad Nacional de Costa Rica. \\ Apdo. 86-3000, Heredia, Costa Rica, CA.
}

\author{
Correspondence \\ A.F. Rojas-Alvarado \\ e-mail: alfrojasa@yahoo.com \\ Recibido: 4 junio 2017 \\ Aceptado: 29 agosto 2017 \\ Publicado on-line: diciembre 2017
}

\author{
Resumen \\ Una nueva especie y tres híbridos en helechos para la Isla del Coco, \\ Puntarenas, Costa Rica
}

Una especie nueva y tres híbridos de helechos para la Isla del Coco (Costa Rica) son descritos e ilustrados aquí: Nephrolepis cocosensis A. Rojas, Cyathea $\times$ robusta A. Rojas, Elaphoglossum x intermedium A. Rojas y Tectaria $x$ epilithica A. Rojas. La nueva especie difiere de Nephrolepis rivularis (Vahl) Mett. ex Krug por su hábitat terrestre, frondas más pequeñas, pinnas más pequeñas and estas perpendicular al raquis, pinnas marginalmente lobuladas a bilobuladas distalmente, escamas del raquis pardo pálido con el punto de inserción pardo oscuro, escamas de la lámina $0.2-0.4 \mathrm{~mm}$ en diámetro, algunas veces reducidas a puntos resinosos, soros submarginales, muchas veces en los lóbulos internos de cada segmento, indusios cordiformes and basalmente adheridos, estos pardo pálidos con el punto de inserción pardo oscuro. El primer híbrido es intermedio entre Cyathea alfonsiana L.D. Gómez y $C$. notabilis Domin, en tamaño del tronco, tamaño y forma de las escamas del rizoma y base del estípite, tamaño de las frondas, pares de venas por segmento and grado de división de estas and y tamaño de los parafisos, pero tiene frondas más grandes que ambos progenitores, por esta razón el nombre del epíteto. Elaphoglossum x intermedium es un híbrido entre E. alvaradoanum A. Rojas y E. crinitum (L.) Christ, el cual es caracterizado por escamas del estípite y lámina pardos, lámina con base cuneada and ápice obtuso, y venas parcial e irregularmente anastomosadas. Tectaria $x$ epilithica tiene caracteres intermedios entre T. incisa Cav. y T. mexicana (Fée) C.V. Morton, y es fácil de reconocer porque tiene lámina 1-pinnado-pinnatífida y tamaño intermedio entre las escamas del rizoma.

Palabras clave: Cyathea, Elaphoglossum, especie nueva, híbridos nuevos, Nephrolepis, Tectaria.

\begin{abstract}
A new species and three new hybrids of ferns from the Cocos Island (Costa Rica) are described here: Cyathea $x$ robusta A. Rojas, Elaphoglossum $x$ intermedium A. Rojas, Nephrolepis cocosensis A. Rojas and Tectaria $x$ epilithica A. Rojas. The new species differs from Nephrolepis rivularis (Vahl) Mett. ex Krug by its terrestrial habitat, smaller fronds, smaller pinnae that are perpendicular to rachis and lobed to bilobed distally, pale brown rachis scales with dark brown insertion points, blade scales $0.2-0.4 \mathrm{~mm}$ in diameter, sometimes reduced to a resinous dots, sori submarginal, frequently in the internal lobe of each segments, and indusia cordiform and basally attached, pale brown with dark brown point of attachment. The first hybrid is intermediate between Cyathea alfonsiana L.D. Gómez and C. notabilis Domin, in trunk tall, size and form of rhizome and stipe scales, fronds size, pairs per segment and division degree of veins and paraphyses size, but has bigger fronds that both progenitors, this character is the basis for its specific epithet. Elaphoglossum $x$ intermedium is a hybrid between E. alvaradoanum A. Rojas and E. crinitum
\end{abstract}


(L.) Christ and is characterized by brown stipe and blade scales, cuneate blade base an obtuse blade apex, and veins partially and irregularly anastomosing. Tectaria $x$ epilithica has intermediate characters between T. incisa Cav. and T. mexicana (Fée) C.V. Morton, this hybrid is easy to recognize because has 1-pinnate-pinnatifid blade and possesses rhizome scales that are intermediate in size compared to those of its parents.

Key words: Cyathea, Elaphoglossum, Nephrolepis, new hybrids, new species, Tectaria.

\section{Introduction}

Some of flora lists from Cocos Island that include ferns are: Hemsley (1882-1886), Robinson (1902), Stewart (1912), Svenson (1938) y Fosberg \& Klawe (1966).

The first list exclusively for ferns from Cocos Island was presented by Gómez (1975a, 1975b) who registered 60 species of ferns and lycophytes and of them only six (10\%) are endemic. After that, other authors as: Gómez (1976) described a new species of Thelypteris Schmidel and reported three species; Smith \& Lellinger (1985) described other new species of Thelypteris; Adams (1992) described a new species of Asplenium L.; Rojas (1996) described a new species of Hymenophyllum Sm. and other in Terpsichore A.R. Sm.; Rojas (2001a) described a new species of Hypolepis Bernh.; Rojas (2003) described two new species of Elaphoglossum Sm.; Rojas (2004) a new variety of Trichomanes collariatum Bosch; Rojas \& Trusty (2004) described two new varieties of Asplenium delicatum C. Presl and Saccoloma elegans Kaulf. respectively, also registered 80 infrageneric taxa and of them eighteen (22.5\%) are endemic. Rojas (2009) described a new species of Elaphoglossum. Rojas (2011) described four new species and registered six other species. Rojas (2013a) described a new species of Stenogrammitis Labiak and Rojas (2013b) described a new species of Danaea Sm. Also Gómez (1976) registered three species and Rojas (2001b) validated the name of Cyathea alfonsiana L.D. Gómez published by Gómez (1971). In summary, 85 infrageneric taxa have been reported and of them twenty five (29.4\%) are endemic.

In this work a new species and three hybrids are described enlarging the diversity to 88 infrageneric taxa and the endemism to $33 \%$ of ferns and lycopodioids from Cocos Island.

\section{Materials and methods}

The new species and hybrids are the result of exhaustive sampling in the Cocos Island and the comparison of specimens with the registered species from Costa Rica and deposited in the National Herbarium (CR), and after the revision of related species and keys from the Neotropics as: Gómez \& Arbeláez (2009), Moran \& Riba (1995), Lellinger (1989). The specimens collected are deposited in Herbario Nacional de Costa Rica (CR), Kew Botanical Garden (K), Missouri Botanical Garden (MO) and Herbario de la Universidad de Costa Rica (USJ).

\section{New species}

Nephrolepis cocosensis A. Rojas, sp. nov. (fig. 1).

TYPE. COSTA RICA. Puntarenas: Puntarenas, Isla del Coco, Parque Nacional Isla del Coco, sendero a Cerro Iglesias, parte alta, $5^{\circ} 31^{\prime} 45^{\prime \prime} \mathrm{N}$, 8704'50"W, 500-634 m, 23 nov 2007, A. Rojas 8191 (holotype: CR; isotypes: K, MO).

Diagnoses. Nephrolepis cocosensis differs from N. rivularis (Vahl) Mett. ex Krug because it has terrestrial habitat, smaller fronds, smaller pinnae and they perpendicular to rachis, pinnae marginally lobulate to bilobulate distally, rachis scales pale brown with the insertion points dark brown, blade scales $0.2-0.4 \mathrm{~mm}$ in diameter, sometimes reduced to a resinous dots, sori submarginal, a lot of times in the internal lobe of each segments, and indusia cordiform and basally attached, they pale brown with dark brown attached point.

Description. Terrestrial; rhizome $3-5 \mathrm{~mm}$ in diameter, ascending, with fimbriate root middle arching (wading estate type); rhizome scales 2-4 x 0.5-1 mm, lanceolate, medium rigid, brown, lustrous, concolorous, marginally denticulate to short-ciliate; tubercles absent; fronds 35-62 cm long, erect or slightly arching, perennial; stipe (7-) 10-18 cm long, pale brown to brown, lustrous, sparsely to moderate scaly, the scales $3-5 x$ ca. 1 $\mathrm{mm}$, pale brown to sometimes dark in the center, 


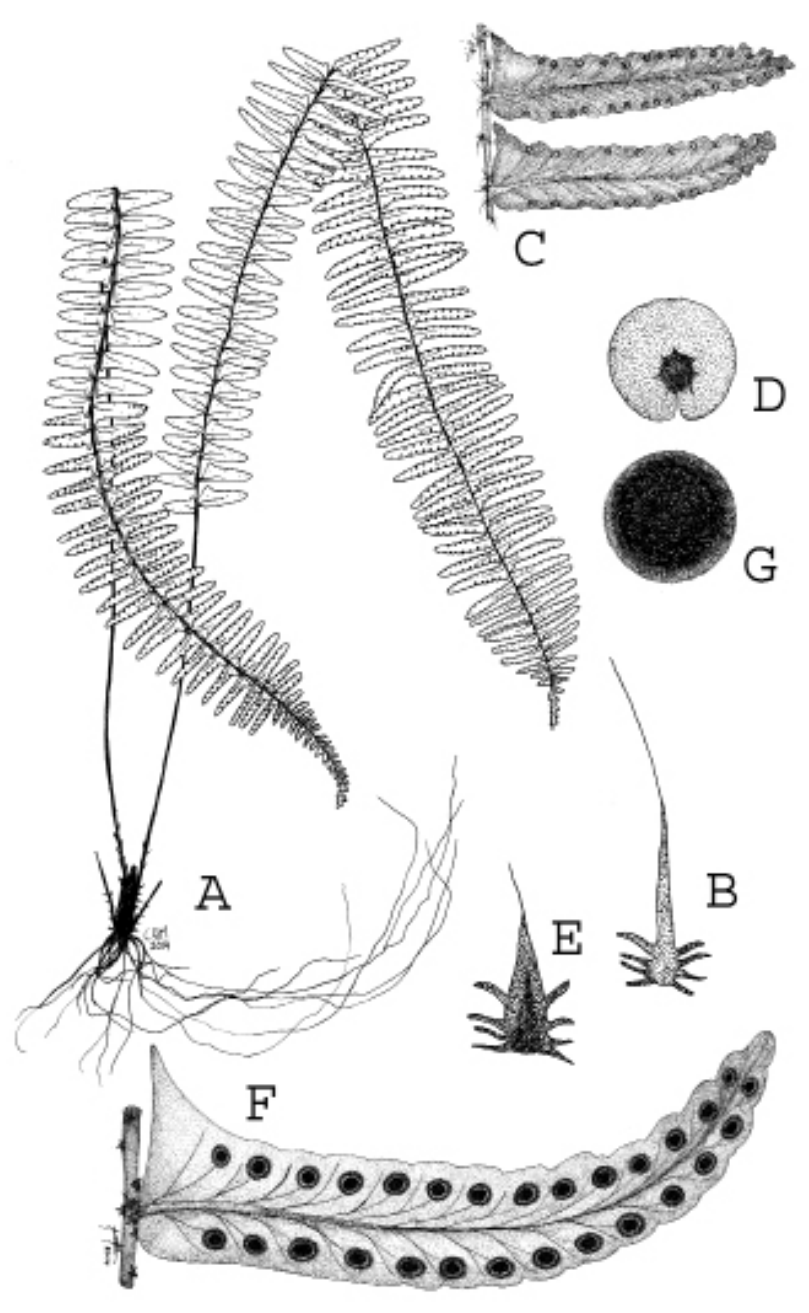

Figure 1. A-D. Nephrolepis cocosensis (A. Rojas 8191, CR): A. General aspect of type specimen. B. Rachis scale. C. Pinna detail. D. Indusium. E-G. Nephrolepis rivularis (A. Rojas et al. 7101, CR): E. Rachis scale. F. Pinna detail. G. Indusium.

marginally entire with erose to short-ciliate base, the scales of medial to distal part to $6 \mathrm{~mm}$ long, linear with expanded base; blade 28-56 x 4-6.7 $\mathrm{cm}$, basally gradually reduced to $2 \mathrm{~cm}$ broad, apically acuminate; rachis smooth, canaliculated dorsally, without trichomes, moderate to densely scaly at the insertion points of the pinnae and adaxially, sparsely scaly dorsally, the scales 1-3.5 $x$ 0.8-1.5 mm, stellate to linear-lanceolate with expanded base, bicolorous, pale brown with dark brown center, marginally ciliate; medial pinnae 2-3.3 $\times 0.4-0.7 \mathrm{~cm}$, suprabasal in insertion, oblong to narrowly triangular-oblong, perpendicular to rachis, the base acroscopically rounded in sterile pinnae to cuneate in fertile pinnae, not overlapping to rachis, the acroscopic lobe deltate in sterile pinnae to acute in fertile pinnae, the apex rounded in sterile pinnae and and acute in the fertile ones;

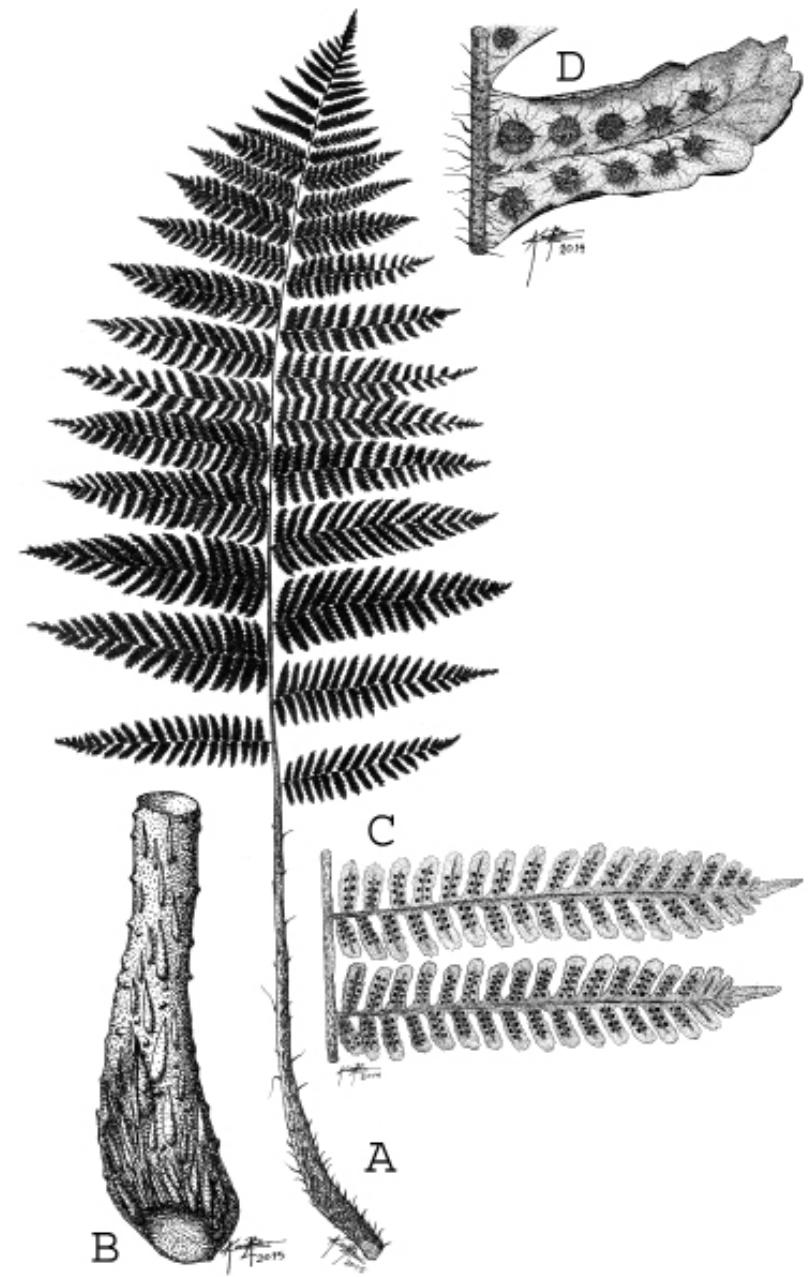

Figure 2. A-D. Cyathea $\times$ robusta ( $A$. Rojas \& J. Chaves 8985, CR). A. Frond. B. Stipe base. C. Pinnae detail. D. Segment detail.

blade glabrous dorsally, sparsely hairy abaxially, the hairs $0.2-0.4 \mathrm{~mm}$ in diameter, dark brown, stellate (sometimes reduced to resinous dots); sori submarginals, sometimes located in the internal lobes of the margin; indusia 0.6-1.2 $\mathrm{mm}$, circular, markedly cordiform at basal side, inserted basally, marginally entire, the insertion point blackish, the rest brown-reddish and finally with a broad pale brown margin.

Distribution. Known only from Cocos Island in Costa Rica at 500-634 m.

Etymology. The name of the new species make reference to the type locality in Cocos Island.

Additional revised specimens. COSTA RICA. Puntarenas: Puntarenas, Isla del Coco, Parque Nacional Isla del Coco, sendero a Cerro Iglesias, en la parte baja entre Cerro Pelón y Cerro Iglesias, $5^{\circ} 31^{\prime} 50^{\prime \prime} \mathrm{N}$, 


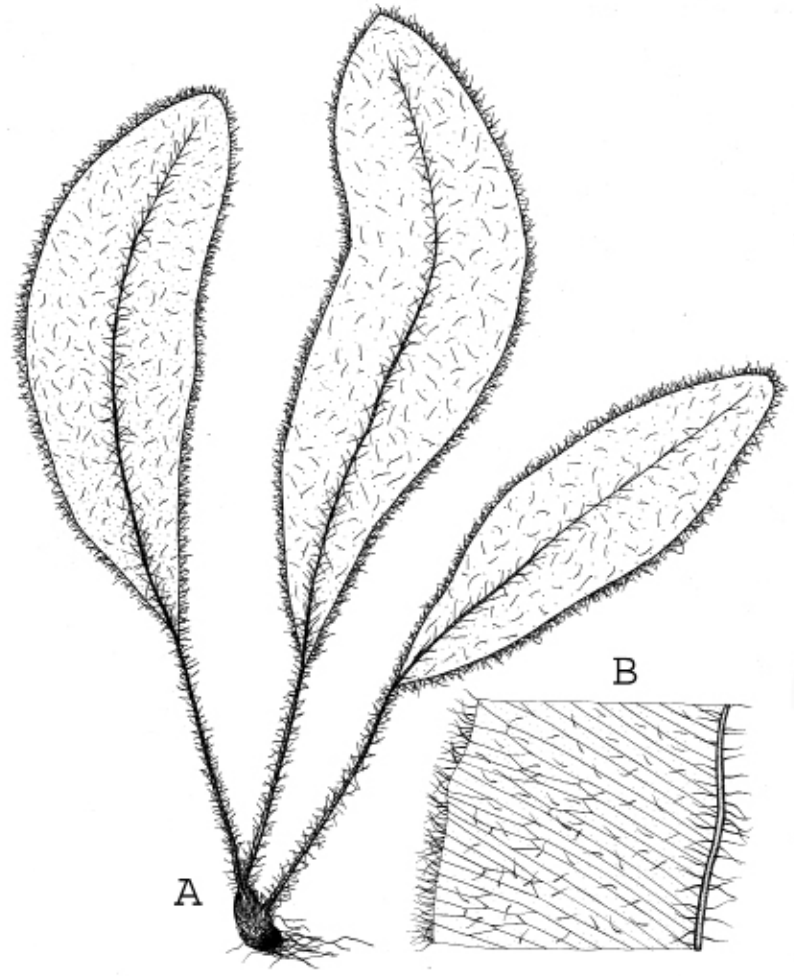

Figure 3. A-B. Elaphoglossum $\times$ intermedium (A. Rojas \& C. Herrera 9281, CR). A. General aspect of type specimen. B. Blade detail.

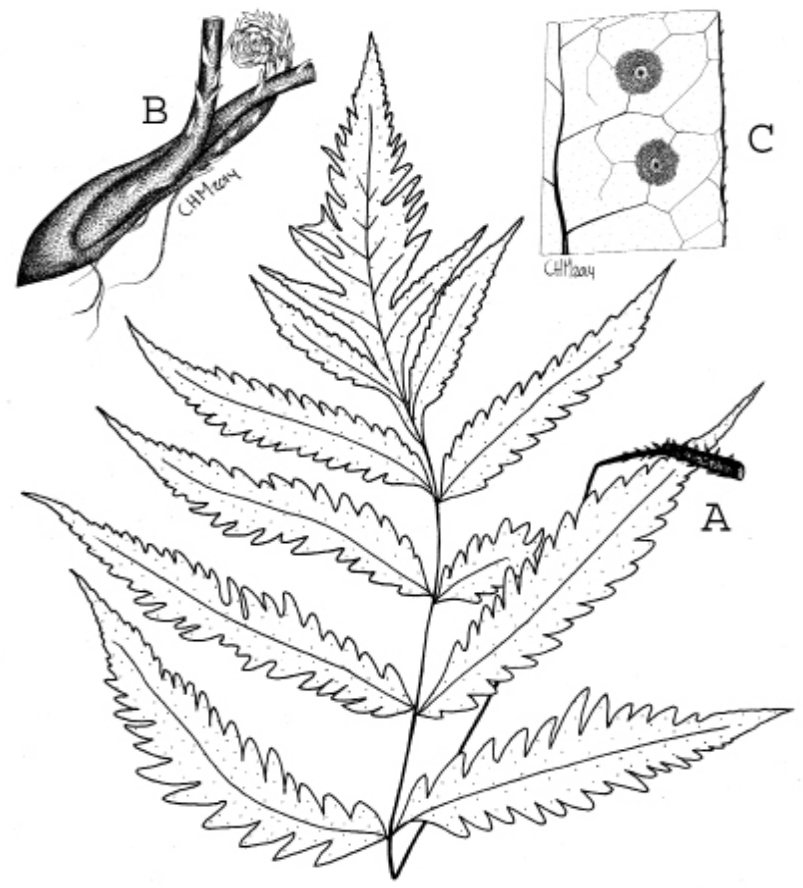

Figure 4. A-C. Tectaria $\times$ epilithica (A. Rojas 8211, CR). A. Frond. B. Rhizome detail. C. Blade detail.

\begin{tabular}{|c|c|c|c|}
\hline Character & C. alfonsiana & C. $\times$ robusta & C. notabilis \\
\hline Trunk tall (m) & $1.5-2.5-7$ & $2-2.7$ & $1-2.5$ \\
\hline Trunk diameter $(\mathrm{cm})$ & $6-10$ & $5-7 \mathrm{~cm}$ & $4-6$ \\
\hline Fronds length (m) & $1-1.5$ & $1.5-1.7$ & $1-1.7$ \\
\hline Size of stipe scales $(\mathrm{mm})$ & $3-8(-12) \times 0.8-1.5$ & $8-15 \times 1.5-2.5(-3)$ & $10-20 \times 2.5-5$ \\
\hline Form of stipe scales & Linear-lanceolate & $\begin{array}{l}\text { Narrowly lanceolate to } \\
\text { linear-lanceolate }\end{array}$ & Ovate to lanceolate \\
\hline Color of central portion of rhizome scales & light brown to brown & Dark brown & Blackish \\
\hline Medial pinnae size $(\mathrm{cm})$ & $25-35 \times 7-14$ & $(30-)$ 42-61 x (9-) 12-22 & $22-30 \times 6-8$ \\
\hline Veins per segment & $7-10$ pairs & $6-8$ pairs & 5-7 pairs \\
\hline Veins division & $1-(-2)$ bifurcate & $\begin{array}{l}\text { bifurcate (the basal ones) } \\
\text { and single (the end ones) }\end{array}$ & single \\
\hline $\begin{array}{l}\text { Paraphysis length (relation with respect } \\
\text { to sporangia) }\end{array}$ & $1-2$ times & $1.5-2.5$ times & (1.5-) 3-4 times \\
\hline
\end{tabular}

Table 1. Morphological comparison among Cyathea $\times$ robusta and the putative progenitors: $C$. alfonsiana, and C. notabilis. 


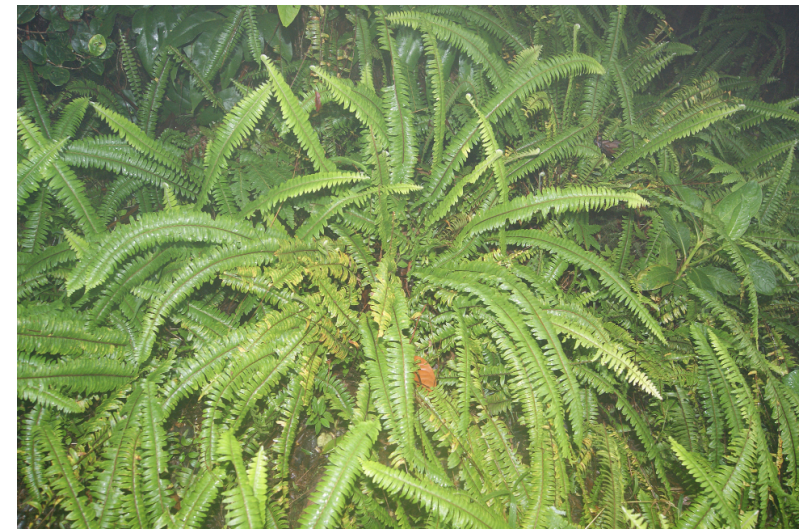

Figure 5. Living plants of Nephrolepis cocosensis

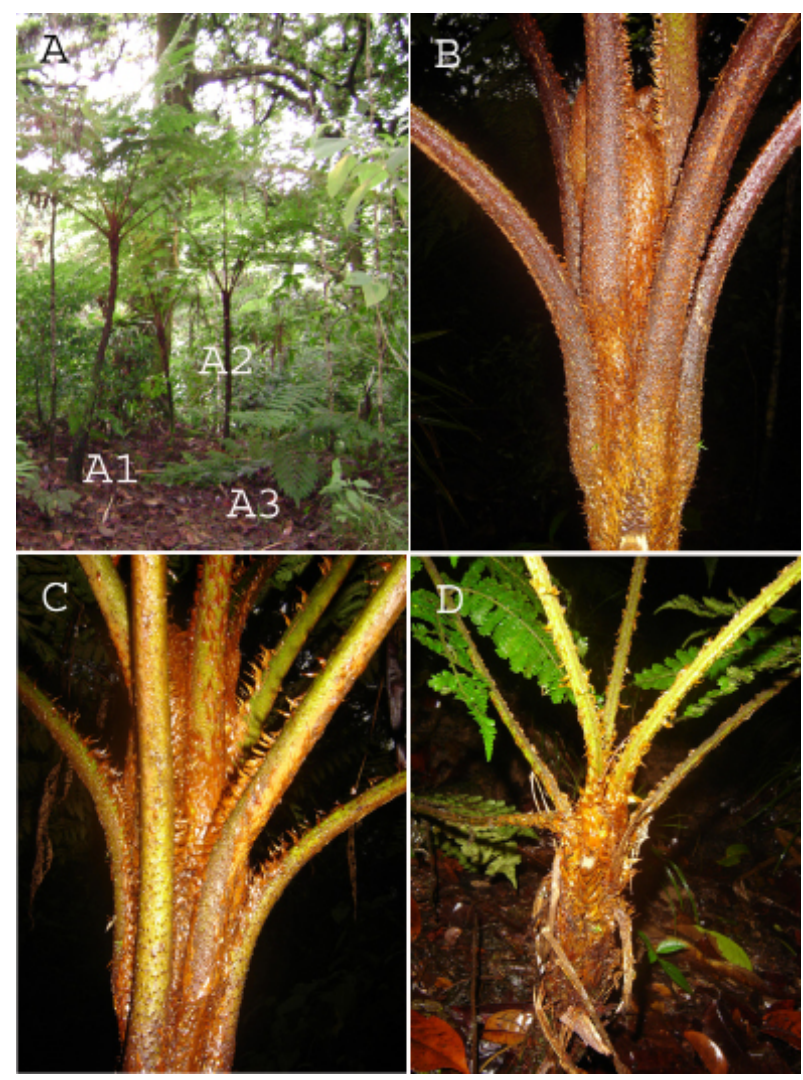

Figure 6. Cyathea alfonsiana: A2. Living plant. B. Trunk detail. C. $\times$ robusta: A1. Living plant. C. Trunk detail. $C$. notabilis: Living plant. D. Trunk detail.

8704'50"W, 500-520 m, 8 ene 2010, A. Rojas \& J.M. Chaves 8950 (CR, K, MO); ibidem, sendero a Cerro Iglesias, en la parte baja entre Cerro Pelón y Cerro Iglesias, 531'50"N, 8704'50”'W, 500-520 m, 31 dic 2010, A. Rojas \& C. Herrera 9279 (CR, MO); Parque Nacional Isla del Coco, $5^{\circ} 31.421^{\prime} \mathrm{N}, 87^{\circ} 04.438^{\prime} \mathrm{W}, 29$ Jan 2002, J. Trusty \& H. Kesler 275 (CR); Parque Nacional Isla del Coco, $5^{\circ} 31.316^{\prime} \mathrm{N}, 87^{\circ} 04.470^{\prime} \mathrm{W}, 4$ feb 2002, J. Trusty \& H. Kesler 366 (CR).
Observations. Nephrolepis cocosensis differs from $N$. rivularis because it has terrestrial habitat (vs. commonly epiphytic), smaller (35-62 $\mathrm{cm}$ long vs. 50-142 (-165) cm) fronds, smaller (2-3.3 cm long vs. $2.8-6.7 \mathrm{~cm}$ ) pinnae and they perpendicular to rachis (vs. falcate, or at less the distal ones), pinnae marginally lobed to bilobed distally (vs. with entire base and serrate to rarely biserrate apex); rachis scales pale brown, with the insertion points dark brown (vs. rachis scales dark brown to blackish centrally), sometimes with teeth pale (vs. brown); sori submarginal, a lot of times in the internal lobe of each segments (vs. medial); indusia cordiform basally attached (vs. peltate with a slight sinus in the basal side), pale brown with the attached point dark brown (vs. dark brown to blackish with a thin pale brown margin); smaller (0.2-0.4 $\mathrm{mm}$ in diameter vs. $0.5-1.2 \mathrm{~mm}$ ) blade scales, sometimes reduced to a resinous dots (vs. sometimes deciduous) (see fig. 1 and 5).

Cyathea $x$ hybrida A. Rojas, nothosp. nov. (fig. 2).

TYPE. COSTA RICA. Puntarenas: Puntarenas, Isla del Coco, Parque Nacional Isla del Coco, Los Llanos, en el sendero a Cerro Iglesias, $5^{\circ} 32^{\prime} 05^{\prime \prime} \mathrm{N}$, 8703'40"W, 240-260 m, 23 ene 2010, A. Rojas \& J. Chaves 8985 (holotype: CR; isotypes: USJ, MO).

Diagnoses. Cyathea $\times$ robusta differs from C. alfonsiana L.D. Gómez by its relative smaller trunk, longer fronds, bigger rhizome scales, bigger pinnae and relative longer paraphyses with respect to sporangia.

Description. Trunk 2-2.7 $\mathrm{m}$ tall, $5-7 \mathrm{~cm}$ in diameter, with scar of deciduous fronds; rhizome scales (5-) 10-15 x (1-) 2-3 mm, narrowly lanceolate to linear-lanceolate, appressed ventrally and patent dorsally, marginally entire; fronds 1.5$1.7 \mathrm{~m}$ long; stipe 45-62 cm long, stramineous to brown basally, densely muricate, ventrally with squamules $0.2-0.5 \mathrm{~mm}$, stellate to ovate, brown, concolorous, marginally dentate to ciliate; stipe scales 8-15 x 1.5-2.5 (-3) mm, linear-lanceolate, gold to brown, sometimes with dark brown center; blade $90-115 \times(60-)$ 80-120 cm, 2-pinnatepinnatifid to 3-pinnate-lobulate, apically pinnatifid; rachis stramineous to pale brown, covered by squamules similar to stipe ones; pinnae sessile or pediculate, the pedicel to $1 \mathrm{~cm}$ long; medial pinnae (30-) 42-61 cm long; costa squamulose and hairy, the squamules $0.3-0.7(-1) \times 0.2-0.5 \mathrm{~mm}$, ovate, brown-gold, the hairs $0.3-0.7(-1) \mathrm{mm}$ long, pale yellowish, moderately appressed, antrorse and very dense in the adaxial surface, patent with curved 


\begin{tabular}{|c|c|c|c|}
\hline Character & E. alvaradoanum & E. $\times$ intermedium & E. crinitum \\
\hline Rhizome diameter (mm) & $3-5$ & $3-5$ & $4-10$ \\
\hline Frond size $(\mathrm{cm})$ & $(15-) 24-42$ & $30-51$ & $(25-)$ 35-80 \\
\hline Stipe size (relation with the frond length) & $(1 / 5-) 1 / 10-1 / 20$ & ca. $1 / 4$ & Ca. $1 / 2$ \\
\hline Blade form & Narrowly oblanceolate & Oblanceolate & Broadly elliptic \\
\hline Blade broad (cm) & $(2.8-) 3.5-4.9 \mathrm{~cm}$ & (8-) 10-20 cm & $6-9 \mathrm{~cm}$ \\
\hline Blade texture & Chartaceous & Chartaceous & Coriaceous \\
\hline Blade ends & $\begin{array}{l}\text { Attenuate at the base, } \\
\text { acuminate at the apex }\end{array}$ & $\begin{array}{l}\text { Basally cuneate, apically } \\
\text { obtuse }\end{array}$ & $\begin{array}{c}\text { Rounded at both } \\
\text { ends }\end{array}$ \\
\hline Long of blade scales (mm) & $3-5$ & $2-5$ & $4-10$ \\
\hline Veins & Free & Partially reticulate & Reticulate \\
\hline
\end{tabular}

Table 2. Morphological comparison among Elaphoglossum $\times$ intermedium and the putative progenitors: E. alvaradoanum and E. crinitum.

apex, retrorse and moderately sparse in abaxial surface, apically sometimes twisted; pinnulae (4.5) $6-11 \times(1.3-)$ 1.7-2.1 cm, sessile; segments of medial pinnae 10-15 pairs, 3-5 $\mathrm{mm}$ broad, serrate (at less in the apex) to pinnatifid; costulae scaly and hairy, with squamules in the basal part similar to the costal ones, the scales 1-2 x 0.7-1.5 mm, ovate, gold, flat, entire, the hairs $1-1.5 \mathrm{~mm}$ long, similar to the costal ones; central vein of segments scaly and hairy, the scales ca. $1 \times 0.5-0.8 \mathrm{~mm}$, ovate, bullate, brown-gold, entire; veins 6-8 pairs per segment, bifurcate (the basal ones) and single (the terminal ones), hairy, the hairs yellowish to whitish; lamina glabrous between the veins; sori medial; paraphyses 1-2 mm long, 1.5-2.5 times longer than the sporangia, conspicuous, colorless to pale yellow; indusia absent.

Distribution. Known only from Cocos Island in Costa Rica at 200-400 m.

Etymology. The name of the new nothospecies refers to its hybrid condition.

Additional revised specimens. COSTA RICA. Puntarenas: Puntarenas, Isla del Coco, Parque Nacional Isla del Coco, camino a Cerro Iglesias, Los Llanos, 532'00” N, 8703'50"W, 200-400 m, 19 nov 2007, A. Rojas 8163 (CR, K, MO); ibidem, Bahía Chatham, costado E hasta la fila arriba de Quebrada Morgan, 533'00”'N, 8702'30"W, 50-200 m, 21 nov 2007, A. Rojas 8175 (CR, K, MO).

Observations. Cyathea $\times$ robusta differs from C. alfonsiana by its relative smaller $(2-2.7 \mathrm{~m}$ vs.
(1.5-) 2.5-7 m) trunk, longer (1.5-1.7 m long vs. 1-1.5 m); bigger (8-15 x 1.5-2.5 (-3) mm x 3-8 $(-12) \times 0.8-1.5 \mathrm{~mm})$ rhizome scales, smaller ((30) $42-61 \times(9-)$ 12-22 cm vs. 25-35 x 7-14 cm) pinnae and relative longer (1.5-2.5 times vs. 1-2 times) paraphysis with respect to sporangia. Also differs from $C$. notabilis by its relative smaller (8-15 x 1.5-2.5 (-3) mm vs. 10-20 x 2.5-5 mm) rhizome scales, smaller ((30-) 42-61 x (9-) 12-22 cm vs. 22-30 x 6-8 cm) pinnae and relative smaller $(1.5-$ 2.5 times vs. (1.5-) 3-4 times) paraphysis with respect to sporangia. Additionally, the number of veins pairs per segment and degree of division are intermediate between the putative progenitors (see fig. 2 and 6; tab. 1).

Elaphoglossum $\underset{x}{\text { intermedium }}$ A. Rojas,
nothosp. nov. (fig. 3). TYPE. COSTA RICA. Puntarenas: Puntarenas, Isla del Coco, Parque Nacional Isla del Coco, Meseta Occidental, en los nacientes de Quebrada Albatros, 531'15"N, 8704'40"W, 350-400 m, 1 ene 2011, A. Rojas \& C. Herrera 9281 (holotype: $\mathrm{CR}$; isotype: $\mathrm{MO}$ ).

Diagnoses. Elaphoglossum $x$ intermedium differs from $E$. alvaradoanum A. Rojas because has proportionately longer stipe, oblanceolate and broader blade, it with cuneate base and obtuse apex and, partially reticulate veins.

Description. Epiphytic; rhizome 3-5 $\mathrm{mm}$ in diameter, compact, ascending; rhizome scales 10-15 x ca. $1 \mathrm{~mm}$, linear, orange-brown, opaque, 


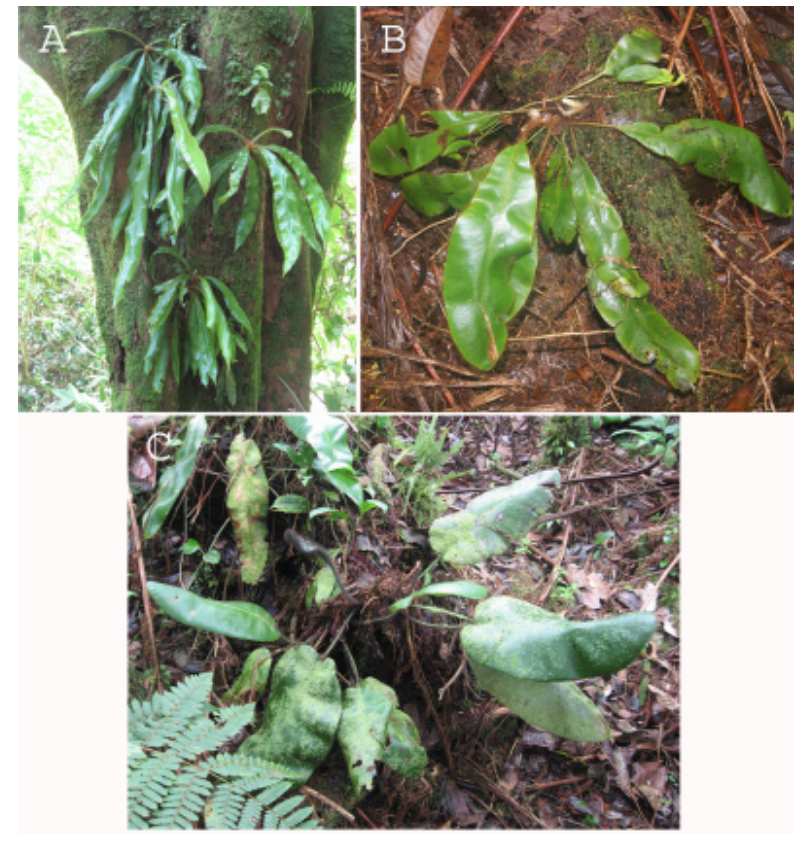

Figure 7. Living plants of: A. Elaphoglossum alvaradoanum: B. E. × intermedium. C. E. crinitum.

flaccid, marginally dentate; fronds $30-51 \mathrm{~cm}$ long, arching; phyllopodium 1-2 cm long, brown, scaly, the scales $5-10 \times 0.3-0.8 \mathrm{~mm}$, orange-brown, marginally entire to dentate, flat; stipe 8-13.5 $\mathrm{cm}$ long, ca. $1 / 4$ of the frond length, yellowish to stramineous, scaly, the scales $3-8 \times 0.2-0.5 \mathrm{~mm}$, subulate, inrolled basally, pale brown to dark brown, dense, marginally entire; blade 22-28 x 6-9 $\mathrm{cm}$, oblanceolate, basally cuneate, apically obtuse; costa stramineous, scaly on both surfaces, more dense abaxially, the scales $3-6 \times 0.2-0.4 \mathrm{~mm}$, linear-lanceolate to linear, brown, marginally entire to denticulate basally; margin and both surfaces scales 2-5 x 0.1-0.3 mm, linear-lanceolate, brown, more dense in the margin; veins 1-3-furcate, rarely and irregularly fused forming areoles, 1.5-2 $\mathrm{mm}$ distant, in angle of $60-70^{\circ}$ with respect to the costa; fertile fronds not seen.

Distribution. Known only from Cocos Island in Costa Rica at 350-400 m elevation.

Etymology. The name of the new nothospecies refers to its intermediate morphology between the putative progenitors.

Observations. Elaphoglossum $\times$ intermedium differs from $E$. alvaradoanum because it has a longer (ca. $1 / 4$ of the frond length vs. (1/5-) 1/10-1/20) stipe, oblanceolate (vs. narrowly oblanceolate) and broader (6-9 cm vs. (2.8-) $3.5-4.9 \mathrm{~cm}$ ) blade

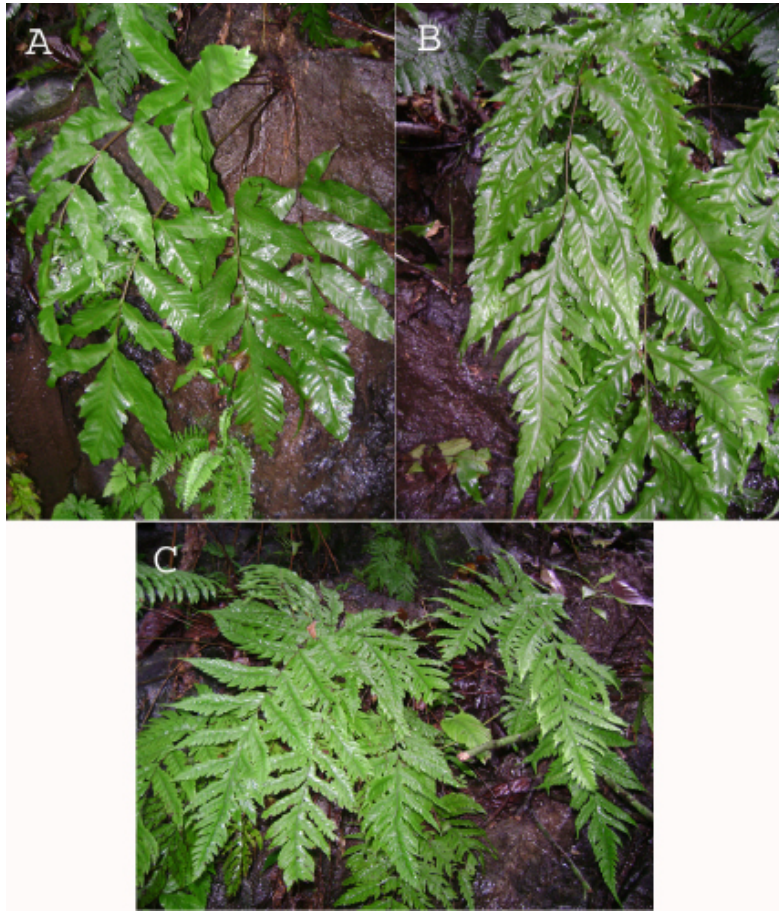

Figure 8. Living plants of: A. Tectaria incisa: B. T. $\times$ epilithica. C. T. mexicana.

with a cuneate (vs. attenuate) base and obtuse (vs. acuminate) apex and partially reticulate (vs. free) veins. Also is similar to E. crinitum (L.) Christ, however the hybrid differs in proportionally shorter (ca. 1/4 of the frond length vs. ca. 1/2) stipe, oblanceolate (vs. broadly elliptic) and narrower (6-9 cm vs. 8-) 10-20 cm) blade, it with cuneate (vs. rounded) base and obtuse (vs. rounded) apex and partially reticulate (vs. completely reticulate) veins. Additionally, the thickness of rhizome, fronds size and blade scale size are intermediate between the putative progenitors (see fig. 3 and 7; Table 2).

Elaphoglossum $x$ intermedium is a hybrid between subsection Apoda Mickel \& Atehortúa and subsection Hymenodium (Fee) Christ, showing that subsections in sect. Polytrichia Christ are closely allied, corroborated by Rouhan et al. (2004) in the figure 2 of their phylogenetic analysis; however, Rojas (2003) showing that sect. Polytrichia is more diverse and complicated that previously mentioned.

Tectaria x epilithica A. Rojas, nothosp. nov. (Fig. 4).

TYPE. COSTA RICA. Puntarenas: Puntarenas, Isla del Coco, Parque Nacional Isla del Coco, cuenca de la Bahía Iglesias, $5^{\circ} 31^{\prime} 00^{\prime \prime} \mathrm{N}, 87^{\circ} 03^{\prime} 55^{\prime} \mathrm{W}$, 75-150 m, 26 nov 2007, A. Rojas 8211 (holotype: CR; isotypes: $\mathrm{K}, \mathrm{US}, \mathrm{USJ}, \mathrm{MO}$ ).

Diagnoses. Tectaria $x$ epilithica differs from T. incisa Cav. by bigger rhizome scales, relatively 


\begin{tabular}{|l|c|c|c|}
\hline Character & T. incisa & T. $\times$ epilithica & T. mexicana \\
\hline Size of rhizome scales $(\mathrm{mm})$ & $0.7-1.5 \times 0.5-1$ & $1.5-3.5 \times 0.5-1.2$ & $3-7 \times 1-2$ \\
\hline Blade size $(\mathrm{cm})$ & $30-70(-100) \times 30-60$ & $60-85 \times 60-75$ & $(20-) 25-50 \times 20-50$ \\
\hline Blade form & Oblong to ovate-oblong & Deltate & Deltate \\
\hline Blade division & 1-pinnate & $\begin{array}{c}\text { 1-pinnate-lobulate to 2- } \\
\text { pinnate-lobulate basally }\end{array}$ & $\begin{array}{c}\text { 2-pinnate-pinnatifid to 3- } \\
\text { pinnate basally }\end{array}$ \\
\hline Size of basal pinnae $(\mathrm{cm})$ & $12-18(-30) \times 2-8$ & $30-40 \times 10-20$ & $10-30 \times 5-20$ \\
\hline Blade indument & Glabrous in both surfaces & $\begin{array}{c}\text { Glabrous in both surfaces, } \\
\text { except sparsely ciliate } \\
\text { marginally }\end{array}$ & $\begin{array}{c}\text { Hairy in both surfaces or } \\
\text { glabrous abaxially, sparsely } \\
\text { ciliate marginally }\end{array}$ \\
\hline
\end{tabular}

Table 3. Morphological comparison among Tectaria $\times$ epilithica and the putative progenitors: T. incisa, and T. mexicana.

larger, deltate and more dissected blade, bigger basal pinnae and sparsely ciliate blade marginally.

Description. Rhizome 10-20 mm in diameter, erect, ascending; rhizome scales 1.5-3.5 x 0.5-1.2 $\mathrm{mm}$, lanceolate, dark brown, glabrous, marginally erose to ciliate; stipe $50-78 \mathrm{~cm}$ long, $2 / 5-1 / 2$ of the frond size, brown to atropurpureous basally, glabrous to sparsely hairy principally in adaxial side, basally scaly, the scales $2-5 \times 1-2 \mathrm{~mm}$, lanceolate, brown, glabrous; blade $60-85 \times 60-75 \mathrm{~cm}$, deltate, 1-pinnate-lobulate to 2-pinnate-lobulate basally, without bud; apical segment deltate to lanceolate, basally cuneate, apically acute, pinnatifid; 4-6 pinna pairs, opposite or subopposite, lobed to pinnate-lobed (the basal ones), the other ones decurrent; basal pinnae 30-40 x 10-20 cm, deltate, inequilateral, with the basiscopic side to three times the acroscopic side; pediculate, the pedicle $0.7-1.5$ $\mathrm{cm}$ long in the acroscopic side and $1.5-3.2 \mathrm{~cm}$ in the basiscopic side, the basal basiscopic pinnulae 10-20 cm long, lobulate; medial pinnae 25-40 x 4-10 cm, oblong, basally cuneate, apically acute to acuminate; rachis brown, hairy, the hairs $0.1-0.2$ $\mathrm{mm}$ long, hyaline to brown, moderate to very dense dorsally, absent to very sparse ventrally; costae stramineous to brown basally, densely hairy dorsally, the hairs pale to dark brown, patent; segments 1-4 $\mathrm{cm}$ long, apically acute to obtuse; veins reticulate, with few free veins included; lamina glabrous on both surfaces, except by hairs $0.1-0.2 \mathrm{~mm}$ long, patent, marginally sparsely ciliate; sori rounded, medial, in a row at each side of the central vein of each segment; indusia circular, peltate, glabrous, marginally entire.

Distribution. Known only from Cocos Island in Costa Rica at 75-150 m elevation.
Etymology. The name of the new nothospecies refers to its epilithic habitat.

Observations. Tectaria $x$ epilithica differs from $T$. incisa by bigger $(1.5-3.5 \times 0.5-1.2 \mathrm{~mm}$ vs. $0.7-1.5 \times 0.5-1 \mathrm{~mm}$ ) rhizome scales, relatively larger $(60-85 \times 60-75 \mathrm{~cm}$ vs. $30-70(-100) \times 30-$ $60 \mathrm{~cm}$ ), deltate (vs. oblong to ovate-oblong) and more dissected (1-pinnate-lobulate to 2-pinnatelobulate basally vs. $1-$ pinnate) blade, bigger (30-40 x 10-20 cm vs. $12-18(-30) \times 2-8 \mathrm{~cm}$ ) basal pinnae and sparsely ciliate (vs. completely glabrous) blade marginally. Also differs from $T$. mexicana by its relative smaller (1.5-3.5 x 0.5-1.2 mm vs. $3-7 \times$ 1-2 mm) rhizome scales, bigger (60-85 x 60-75 $\mathrm{cm}$ vs. 20-) $25-50 \times 20-50 \mathrm{~cm}$ ) and less dissected (1-pinnate-lobed to 2-pinnate-lobed basally vs. 2-pinnate-pinnatifid to 3-pinnate basally) blade, bigger $(30-40 \times 10-20 \mathrm{~cm}$ vs. $10-30 \times 5-20$ $\mathrm{cm}$ ) basal pinnae and glabrous (vs. hairy) blade surfaces. (see fig. 4 and 8 ; Table 3).

\section{Acknowledgments}

Thanks the curators of the herbaria of the Museo Nacional de Costa Rica (CR), Missouri Botanical Garden (MO), herbario de la Universidad de Costa Rica (USJ) and National Museum of Natural History herbarium (US) for specimen loans, to Weston Testo for reviewing the English translation, to Christian Herrera Martínez and Karen Bermúdez Barrantes for the excellent illustrations, and the anonymous reviewers for their helpful suggestions.

\section{References}

Adams, C.D. (1992). Eleven new species, a new variety, and a new varietal combination in the fern genera 
Asplenium and Diplazium in Central America. Novon, 2, 290-298.

Fosberg, F.R. \& W.L. Klawe. (1966). Preliminary list of plants from Cocos Island. In: R. I. Bowman (ed.). The Galápagos: Procceding of the Symposia of the Galápagos International Scientific Proyect. Univ. Calif. Press. Berkeley, California.

Gómez, L.D. (1971). Two new tree ferns from Costa Rica. Amer. Fern J., 61, 166-170.

Gómez, L.D. (1975a). Contribuciones a la Pteridología Costarricense. VII. Pteridofitos de la Isla Cocos. Brenesia, 6, 33-48.

Gómez, L.D. (1975b). The ferns and Fern-allies of Cocos Island, Costa Rica. Amer. Fern J., 65 (4), 102-104.

Gómez, L.D. (1976). Contribuciones a la Pteridología Costarricense. X. Nuevos pteridofitos de la Isla de Cocos. Brenesia, 8, 97-101.

Gómez, L.D. \& Arbeláez, A.L. (2009). Flora de Nicaragua. Tomo IV: helechos. Missouri Botanical Garden, St. Louis, Missouri, USA. 348 p.

Hemsley, W.B. (1882-1886). Botany, vol. 3. In: F. D. Godman y O. Salvin (eds.). Biologia CentraliAmericana.

Lellinger, D.B. (1989). The ferns and fern-allies from Costa Rica, Panama, and the Chocó.

Moran R.C. \& Riba, R. (eds.). (1995). Flora Mesoamericana. Vol.1. Psilotaceae a Salviniaceae. Universidad Nacional Autónoma de México. 470 p.

Robinson, B.L. (1902). Contributions from the Grey Herbarium of Harvard University. New Series. No. 24. Flora of the Galápagos Islands. Proc. Amer. Acad. Sci., 38(4), 77-269.

Rojas, A.F. (1996). Aportes a la Flora Pteridophyta Costarricense. II. Taxones nuevos. Brenesia, 45-46, 33-50.

Rojas, A.F. (2001a). Seis especies nuevas y dos nuevos registros de helechos (Pteridophyta) para Costa Rica. Rev. Biol. Trop., 49 (2), 435-452.

Rojas, A.F. (2001b). Nuevas especies, nombres nuevamente utilizados y nuevas distribuciones en los helechos arborescentes (Filicales: Cyatheaceae) para el neotrópico. Rev. Biol. Trop., 49 (2), 453-466.

Rojas, A.F. (2003). New taxa in the Elaphoglossum sect. Elaphoglossum subsect. Pachyglossa (Lomariopsidaceae) from Mexico and Central America. Rev. Biol. Trop., 51 (1), 1-32.

Rojas, A.F. (2004). Una especie nueva de Hymenophyllum y una variedad de Trichomanes collariatum Bosch (Filicales: Hymenophyllaceae) para Costa Rica. Lankesteriana, 4(2), 147-152.

Rojas, A.F. (2011). New species and new records of ferns (Pteridophyta: Polypodiales) from Cocos Island, Costa Rica. Brenesia, 75-76, 7-15.

Rojas, A.F. (2013a). Novelties in Grammitis Sw. and Stenogrammitis Labiak (Polypodiaceae) from Costa Rica, Colombia, and Venezuela. Actual. Biol., 35 (98), 5-10.

Rojas, A.F. (2013b). Notas taxonómicas en Danaea Sm. (Marattiaceae) para Costa Rica, Panamá y Colombia. Actual. Biol., 35 (98), 11-20.

Rojas, A.F. \& Trusty, J. (2004). Diversidad Pteridofítica de la Isla del Coco, Costa Rica. Brenesia, 62, 1-14.

Rouhan, G., Dubuisson, J., Rakotondrainibe, F., Motley, T.J., Mickel, J.T., Labat, J. \& Moran, R.C. (2004). Molecular phylogeny of the fern genus Elaphoglossum (Elaphoglossaceae) based on chloroplast non-coding DNA sequences: contributions of species from the Indian Ocean area. Mol. Phylogenet. Evol., 33 (2004), 745-763.

Smith, A.R. \& D.B. Lellinger. (1985). New tropical American species of Thelypteris (Pteridophyta). Proc. Soc. Wash., 98 (4), 916-930.

Stewart, A. (1912). Expedition of the California Academy of Sciences to the Galápagos Islands. 1905-1906. V. Notes of the botany of Cocos Island. Proc. Calif. Acad. Sci., fourth ser., vol. 1, 375-404.

Svenson, H. (1938). Pteridophyta of the Galápagos and Cocos Islands. Bull. Torrey Bot. Club 65, 303-333. 
